ISSN. 2621-9832

JURNAL MathEdu (Mathematic Education Journal) http://journal.ipts.ac.id/index.php/MathEdu Vol. 4. No. 3 November 2021

\title{
PENERAPAN MODEL PEMBELAJARAN THINK PAIR SHARE DALAM UPAYA PENINGKATAN HASIL BELAJAR DAN AKTIVITAS SISWA PADA MATERI PERSAMAAN LINIER SATU VARIABEL
}

\author{
Oleh : \\ *Fitriani ${ }^{1}$, Yuni Rhamayanti ${ }^{2}$, Adek Nilasari Harahap ${ }^{3}$ \\ Fakultas Keguruan dan Ilmu Pendidikan, Universitas Graha Nusantara Padangsidimpuan
}

\begin{abstract}
Abstrak
Penelitian ini merupakan Penelitian Tindakan Kelas. Dalam penelitian ini disusun perangkat pembelajaran : Rencana Pelaksanaan Pembelajaran, Buku Panduan Guru dan Lembar Kerja Siswa. Selanjutnya menyusun instrumen tes essay dan lembar observasi siswa, sebelum instrumen tes digunakan terlebih dahulu di uji coba dan hasilnya digunakan untuk instrumen penelitian. Penelitian ini dilaksanakan melalui 2 siklus sebelum diberikan tindakan terlebih dahulu diberikan diberikan tes diagnostik dengan kategori minimal cukup diperoleh 40,91\%. Selanjutnya diberikan tes hasil belajar matematika siklus I adalah 77,27 meningkat menjadi 86,36 pada siklus II. Persentase akivitas aktif siswa meningkat,hal ini diperoleh dari rata-rata kadar aktivitas siswa pada siklus I sebesar 76\% kemudian pada siklus II naik menjadi 85,28. Kemampuan guru mengelola pembelajaran siklus I dan siklus II termasuk dalam kategori - Baikll. Berdasarkan Hasil tersebut maka penelitian ini menyarankan penerapan model pembelajaran Think Pair Share untuk meningkatkan hasil belajar matematika siswa dikelas VII-3 SMP Negeri 2 Batahan.
\end{abstract}

Kata kunci-Hasil belajar, Aktivitas siswa, Model pembelajaran Think Pair Share

\begin{abstract}
This research is a Classroom Action Research. In this research, learning tools are arranged: Lesson Plans, Teacher's Guidebooks and Student Worksheets. Next, arrange essay test instruments and student observation sheets, before the test instruments are used, they are tested first and the results are used for research instruments. This research was carried out through 2 cycles before being given action, first given a diagnostic test with a minimum category of enough to get $40.91 \%$. Furthermore, given a test of mathematics learning outcomes in the first cycle, it was 77.27 which increased to 86.36 in the second cycle. The percentage of active student activity increased, this was obtained from the average level of student activity in the first cycle of $76 \%$ then in the second cycle it rose to 85.28. The teacher's ability to manage learning cycle I and cycle II is included in the "Good" category. Based on these results, this study suggests the application of the Think Pair Share learning model to improve students' mathematics learning outcomes in class VII-3 of SMP Negeri 2 Batahan.
\end{abstract}

Keywords — Learning outcomes, Student activities, Think Pair Share Learning Model

\section{PENDAHULUAN}

Pendidikan merupakan upaya untuk meningkatkan kualitas setiap individu, secara langsung disiapkan untuk menopang dan mengikuti laju perkembangan ilmu pengetahuan dan teknolagi dalam upaya meningkatkan mutu pendidikan yang sejalan dengan proses belajar-mengajar. Menurut Sardiman, (2007) : "Proses belajar-mengajar merupakan kegiatan interaksi antara dua unsur manusiawi, yaitu siswa sebagai pihak yang belajar dan guru sebagai pihak yang mengajar, dengan siswa sebagai subjek pokoknya". Upaya untuk meningkatkan mutu pendidikan itu sudah banyak dilakukan oleh pemerintah diantaranya pembaharuan kurikulum, perbaikan sarana dan prasarana pendidikan, penggunaan metode mengajar, melaksanakan penelitian serta meningkatkan kualitas dan kuantitas bahan ajar. Namun banyaknya upaya yang dilakukan pemerintah hingga saat ini masih banyak mendapat kritikan dari media 
ISSN. 2621-9832

JURNAL MathEdu (Mathematic Education Journal) http://journal.ipts.ac.id/index.php/MathEdu Vol. 4. No. 3 November 2021

massa yang mengatakan bahwa mutu pendidikan di Indonesia masih rendah. Hal yang sama dikemukakan oleh Priatmoko (dalam Susanto, 2004: 3) bahwa "mutu pendidikan masih rendah, indikator rendahnya mutu pendidikan ini dapat dilihat pada hasil belajar siswa".

Rendahnya hasil matematika ini disebabkan masih banyak siswa yang mengalami kesulitan dalam belajar matematika sebagai ilmu yang sukar, sehingga menimbulkan rasa takut dalam belajar matematika. Upaya untuk meningkatkan mutu pendidikan itu sudah banyak dilakukan oleh pemerintah diantaranya pembaharuan kurikulum, perbaikan sarana dan prasarana pendidikan, penggunaan metode mengajar, melaksanakan penelitian serta meningkatkan kualitas dan kuantitas bahan ajar. Namun banyaknya upaya yang dilakukan pemerintah hingga saat ini masih banyak mendapat kritikan dari media masa yang mengatakan bahwa mutu pendidikan di Indonesia masih rendah.

Seperti yang diungkapkan oleh Slameto (2003) bahwa:'Metode mengajar guru yang kurang baik diakibatkan karena guru kurang persiapan dan kurang menguasai bahan pelajaran sehingga guru tersebut menyajikannya tidak jelas atau sikap guru terhadap siswa atau mata pelajaran itu sendiri tidak baik, sehingga siswa kurang senang terhadap pelajaran atau gurunya, akibatnya siswa malas untuk belajar dan mencatat materi pelajaran yang sedang dipelajari”.

Selama ini guru dipandang sebagai sumber informasi utama, namun karena semakin majunya teknologi maka siswa dapat dengan mudah mendapatkan informasi yang dibutuhkannya, maka guru seharusnya tanggap dan mampu menyesuaikan diri terhadap perkembangan tersebut. Salah satu yang dapat dilakukan adalah menerapkan peran guru sebagai fasilitator dan katalisator. Peran guru sebagai fasilitator adalah memfasilitasi proses pembelajaran yang berlangsung dikelas. Guru memilih atau merancang rencana pembelajaran yang sesuai dengan kondisi kelas dan berusaha mengarahkan siswa untuk berperan aktif dan bertanggung jawab terhadap proses serta hasil pembelajaran. Sedangkan peran guru sebagai katalisator adalah guru membantu siswa dalam menemukan kekuatan, talenta dan kelebihan mereka. Guru bertindak sebagai pembimbing yang mampu menumbuhkan dan mengembangkan rasa cinta siswa akan proses pembelajaran serta membantu siswa untuk mengerti cara belajar yang optimal.

Berdasarkan hasil tes diagnostik yang dilakukan maka dapat diperoleh bahwa siswa yang berkemampuan tinggi sebanyak 10 orang atau (37.04\%) dari 28 orang siswa dan berkemampuan rendah sebayak 18 orang atau $(62.96 \%)$, hal ini ditunjukkan dalam kategori skala 5 yaitu : kategori sangat baik diperoleh 3 orang (15\%), kategori baik diperoleh 4 orang (11\%), kategori cukup diperoleh 3 orang (11\%), kategori kurang 3 orang (11\%), kategori sangat kurang 14 orang (52\%), ini menunjukkan bahwa tingkat kemampuan belajar siswa dalam pembelajaran matematika pada materi persamaan linear satu variabel masih kurang dari syarat penelitian ini karena hasil belajar siswa kurang dari $80 \%$.

Menyadari hal tersebut, perlu adanya suatu pembaharuan dalam pembelajaran untuk memungkinkan siswa dapat mempelajari matematika lebih mudah, lebih cepat, lebih bermakna, efektif dan menyenangkan. Salah satu usaha yang dapat digunakan untuk mengatasi permasalah tersebut dengan penerapan model pembelajaran kooperatif tipe TPS (Think-Pair-Share) sesuai dengan pendapat Trianto (2011) menyatakan bahwa : Think Pair Share (TPS) merupakan suatu cara yang efektif untuk membuat variasi suasana pola diskusi. Dengan asumsi bahwa semua resitasi atau diskusi membutuhkan pengaturan untuk mengendalikan kelas secara keseluruhan, dan prosedur yang digunakan dalam Think Pair Share dapat memberi siswa lebih banyak waktu berpikir, untuk merespon dan saling membantu.

Model pembelajaran tipe Think Pair Share (TPS) adalah salah satu model pembelajaran yang menarik, karena selain siswa berkerja secara kelompok seperti model pembelajaran kooperatif lainnya, siswa juga bekerja secara individu. Inilah yang membedakan model pembelajaran kooperatif tipe TPS dengan model pembelajaran kooperatif lainnya. Tahapan-tahapan dalam TPS yaitu Thinking, Pairing Share diharapkan dapat membuat siswa lebih kreatif, cepat dan tepat dalam memecahkan masalah matematika. Melalui model pembelajaran ini juga dapat meningkatkan sikap positif siswa terhadap matematika serta mendorong siswa untuk berpartisipasi lebih aktif.

\section{METODE PENELITIAN}

Jenis penelitian ini merupakan Penelitian Tindakan Kelas. Penelitian tindakan kelas atau PTK (Classroom Action Research) dapat diartikan suatu kegiatan ilmiah yang dilakukan oleh guru di kelasnya sendiri dengan jalan merancang, melaksanakan, mengamati, dan merefleksikan tindakan melalui beberapa siklus yang bertujuan untuk memperbaiki atau meningkatkan mutu proses pembelajaran di kelasnya.

Subjek penelitian merupakan kasus atau orang yang ikut serta dalam peneliti mengukur variabelvariabel penelitiannya. Adapun yang menjadi subjek dalam penelitian ini adalah siswa kelas VII-3 SMP Negeri 2 Batahan tahun ajaran 2020-2021 dengan jumlah siswa terdiri dari 22 orang, perempuan sebayak 11 orang dan laki-laki sebanyak 11 orang. 
ISSN. 2621-9832

JURNAL MathEdu (Mathematic Education Journal) http://journal.ipts.ac.id/index.php/MathEdu

Vol. 4. No. 3 November 2021

Penelitian ini menggunakan model spiral yang dikembangkan oleh Kemmis dan Taggart. Dalam model ini terdapat 4 tahap yang harus dilakukan yaitu :

1. perencanaan (planing),

2. pelaksanaan (action),

3. pengamatan (observing),

4. refleksi (reflecting)

Teknik pengumpulan data merupakan langkah yang paling utama dalam penelitian. Karena tujuan utama dari penelitian adalah untuk mendapatkan data. karena pada tahap ini hasil penelitian dapat dirumuskan setelah semua data terkumpul. Adapun teknik pengumpulan data pada penelitian ini adalah : lembar tes dan lembar observasi.

Data yang diperoleh dalam penelitian ini berupa lember observasi proses pembelajaran, serta tes hasil belajar. Analisis data yang digunakan dalam penelitian ini adalah dengan menelaah seluruh sumber tersebut. Teknik analisis data dalam penelitian ini adalah analisis dekstriptif untuk mengetahui pelaksanaan dan hambatan-hambatan yang terjadi dalam pembelajaran dengan model pembelajaran kooperatif tipe Think Pair Share dan analisis kuantitatif untuk mengetahui peningkatan hasil belajar dan aktivitas matematika siswa.

Indikator keberhasilan penelitian tindakan kelas (PTK) ini dapat dilihat dari :

1. Keberhasilan kelas dilihat dari apabila rata-rata hasil belajar matematika meningkat yang di tandai dari hasil tes setelah siswa diberi tindakan mencapai $80 \%$ siswa memperoleh nilai minimal "cukup" dari siswa yang mengikuti tes pada penerapan model pembelajaran kooperatif tipe Think Pair Share (TPS) dalam pembelajaran matematika pada materi Persamaan Linier Satu Variabel di SMP Negeri 2 Batahan.

2. Meningkatnya kadar aktivitas siswa dalam proses pembelajaran yang dilihat dari lembar observasi dengan persentasi ketercapaian minimal $80 \%$ dari seluruh aspek yang diamati.

3. Meningkatnya tingkat kemampuan guru untuk tiap pertemuan mencapai kriteria minimal baik dengan persentase ketercapaian minimal baik dari seluruh aspek yang diamati.

Jika indikator ini tercapai maka siklus dalam penelitian ini akan berakhir dan di hentikan, upaya meningkatkan hasil belajar dan aktivitas matematika siswa pada materi Persamaan Linier Satu Variabel dengan menerapkan model pembelajaran kooperatif tipe Think Pair Share dianggap berhasil.

\section{HASIL DAN PEMBAHASAN}

Penelitian Tindakan Kelas ini dilaksanakan untuk meningkatkan keaktifan dan hasil belajar siswa kelas VII di SMP Negeri 2 Batahan. Penelitian ini terlaksana dalam 2 siklus, siklus I terdiri dari 3 kali pertemuan, pertemuan ke-1 dan ke-2 materi, pertemuan ke-3 untuk evaluasi siklus I. Kemudian siklus II terdiri dari 2 kali pertemuan, pertemuan ke-1 materi dan pertemuan ke-2 untuk evaluasi siklus II. Penelitian ini membutuhkan waktu kurang lebih satu bulan untuk observasi, riset maupun setelah riset.

Peningkatan hasil belajar siswa dilihat berdasarkan hasil tes siswa pada siklus I terdapat 16 orang siswa dengan persentase penilaian 77,27\% dari 22 siswa pada kategori "Cukup", pada siklus II terdapat 19 orang siswa dengan persentase penilaian 86,36\% dari 22 siswa dengan kategori "Baik". Maka ada peningkatan dari siklus I ke siklus II sebesar 9,09\% Jadi dengan penerapan model pembelajaran Think Pair Share dapat meningkatkan hasil belajar matematika siswa pada pokok bahasan persamaan linier satu variabel. Adapun grafik hasil penelitian secara keseluruhan dari siklus I dan siklus II disajikan dalam gambar berikut :

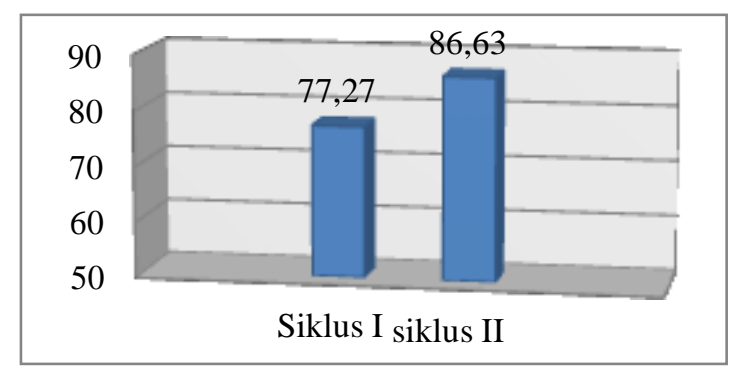

Gambar 1. Grafik Hasil penelitian secara keseluruhan 
ISSN. 2621-9832

JURNAL MathEdu (Mathematic Education Journal) http://journal.ipts.ac.id/index.php/MathEdu Vol. 4. No. 3 November 2021

Bila ditinjau dari segi aktivitas siswa pada siklus I yang tidak memenuhi kriteria yang ditentukan, dimana aktivitas siswa pada siklus I hanya $76 \%$ dengan kategori "Cukup". Sedangkan pada siklus II meningkat sebanyak 9,28\% yaitu menjadi 85,28\% dengan kategori "Baik". Aktivitas siswa ini meningkat baik disebabkan kerjasama yang baik siswa dan guru atau siswa itu sendiri. Jadi didalam proses pembelajaran terjadi interaksi antara guru dan siswa atau siswa itu sendiri. Hal ini mengakibatkan suasana kelas menjadi kondusif, dimana masing-masing siswa dapat melibatkan kemampuannya semaksimal mungkin. Aktivitas yang timbul dari siswa akan mengakibatkan pila terbentuknya pengetahuan dan keterampilan yang akan mengarah pada peningkatan prestasi. Adapun grafik dari akivitas belajar siswa siklus I dan siklus II yaitu.

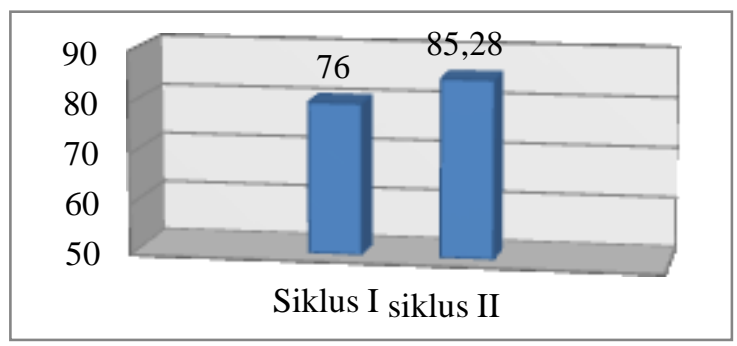

\section{Gambar 2. Grafik Persentasi Aktivitas secara keseluruhan}

Hasil observasi aktivitas guru yang dilakukan menunjukkan bahwa pelaksanaan dengan model pembelajaran Think Pair Share pada pokok bahasan persamaan linier satu variabel dalam penelitian ini berjalan dengan baik dan mengalami peningkatan. Dengan demikian model pembelajaran Think Pair Share dapat dipertimbangkan untuk meningkatkan mutu pembelajaran.

Berdasarkan hasil observasi kemampuan guru mengelola pembelajaran, pada siklus II berada pada kategori "baik" dan juga pada setiap aspek pengamatan mendapat nilai "baik". Hal ini dapat dilihat dari pengamatan observer dari siklus I. dapat disimpulkan dari hasil penelitian, kemampuan guru mengelola pembelajaran sudah baik atau guru telah mampu menerapkan metode pembelajaran tersebut sehingga dapat meningkatkan hasil belajar matematika siswa. Adapun grafik dari kemampuan guru mengelola pembelajaran siklus I dan siklus II yaitu.

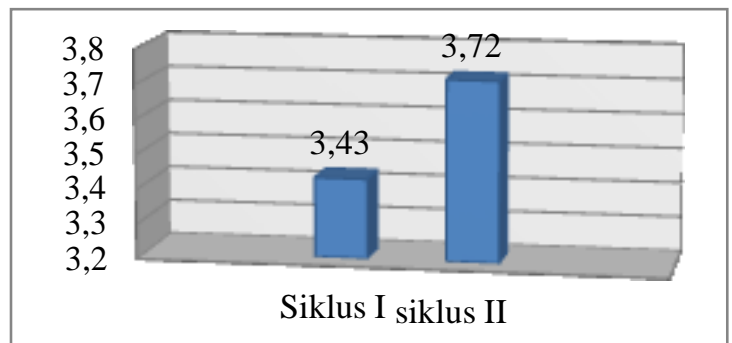

Gambar 3. Grafik Kemampuan guru mengelola pembelajaran secara keseluruhan

\section{KESIMPULAN} berikut :

Berdasarkan hasil penelitian tindakan kelas ini penelitian memberikan kesimpulan sebagai

1. Model pembelajaran Think Pair Share dapat meningkatkan hasil belajar matematika siswa pada pokok bahasan persamaan linier satu variabel di kelas VII-3 SMP Negeri 2 Batahan tahun Ajaran 2020-2021. Sebelum dilaksanakannya tindakan di peroleh bahwa hasil belajar matematika siswa di kelas VII-3 masih jauh dengan kriteria yang di harapkan, hal ini di peroleh dari hasil tes diagnostik yaitu sebesar 40,91\%. Setelah di laksanakannya tindakan PTK dapat dilihat dari hasil tes hasil belajar siswa pada siklus I 77,27 \% dan pada siklus II 86,36\%. Hasil yang didapat pada siklus II menunjukkan bahwa sudah dapat terpenuhi kategori yang diharapkan yaitu minimal $80 \%$.

2. Aktivitas siswa di kelas VII-3 meningkat dengan penggunaan model pembelajaran Think Pair Share. Hal ini dapat dilihat dari hasil observasi aktivitas siswa siklus I 76\% dan siklus II 85,28\%. Hasil yang diperoleh telah terpenuhi yaitu minimal $80 \%$. 
3. Kemampuan guru mengelola pembelajaran di kelas VII-3 meningkat dengan penggunaan model pembelajaran Think Pair Share. Hal ini didukung dengan kategori yang didapat pada Siklus II yaitu kategori "Baik" dan pada siklus I sebelumnya mendapat kategori "Baik" juga, namun jika diperhatikan pada setiap aspek pengamatan ada satu aspek yang masih memenuhi kriteria pada siklus

I. Untuk itu hasil yang diharapkan telah terpenuhi karena sudah sesuai dengan kategori minimal "Baik" dan disetiap aspek pengamatan juga "Baik" pada siklus II.

\section{REFERENSI}

Ahmad, Susanto. (2013). Teori Belajar dan Pembelajaran di Sekolah Dasar. Jakarta: Kencana Prenada Media Group

Arikunto, S., (2002), Prosedur Penelitian Suatu Pendekatan Praktek, Rineka Cipta, Jakarta.

Kamdi, Waras. 2007. Model-model Pembelajaran Inovatif. Malang: Universitas Negeri Malang.

Nasution, Muhammad Akid, Agus Makmur Panjaitan, And Adek Nilasari Harahap. "Pengaruh Penerapan

Model Pembelajaran Kooperatif Tipe Think Pair And Share Terhadap Kemampuan Pemecahan Masalah Siswa Pada Materi Bentuk Aljabar Kelas Vii Mts Ypks Padangsidimpuan." Eksakta: Jurnal Penelitian Dan Pembelajaran Mipa 6.2 (2021): 235-241.

Ngalim Purwanto. (2007). Psikologi Belajar. Bandung: PT Remaja Rosdakarya.

Nurkancana, Wayan, 1986, Evaluasi pendidikan, Indonesia: Usaha Nasional.

Sardiman, A.M., (2007), Interaksi dan Motivasi Relajar Mengajar, PT. Graznido Persada, Jakarta.

Slameto, (2003), Belajar dan Faktor - Faktor yang Mempengaruhinya, Rineka Cipta, Jakarta.

Trianto, S.Pd, M.Pd, (2007), Model-Model Pembelajaran Inovatif Berorientasi Konstruktivistik, Penerbit Prestasi Pustaka.

User, U., (2002), Menjadi Guru Profesional, Remaja Rosdakarya, Bandung. 